\title{
Design of Three-Phase Induction Motor Starting Drive Based on Electromagnetic Torque Analysis
}

\author{
Denny Irawan ${ }^{1)}$, Pressa Perdana SS ${ }^{2)}$, Danial Palupessy ${ }^{3)}$ \\ ${ }^{1,2,3)}$ Universitas Muhammadiyah Gresik, Gresik, 61121, Indonesia \\ 1den2mas@umg.ac.id, ${ }^{2}$ Pressa@umg.ac.id, ${ }^{3}$ Dani.alves791@gmail.com
}

\begin{abstract}
The process of starting a three-phase induction motor consumes a very large current from the power grid, which can cause voltage drops and damage the coil insulators due to the heat generated. However, this has been overcome by using several starting methods including star-delta starter, starter with autotransformer, soft starter, and drive frequency or better known as VFD or VSD. In conventional soft starters, a small reduction in voltage results in a sizable drop in electromagnetic torque. This can cause a motor with a certain load to fail to start. In this research, a three-phase induction motor soft starter modeling will be carried out using the method of setting the source voltage and frequency, designed to overcome the low electromagnetic torque generated by conventional soft starters. The modeling of the soft starter with thyristor control is expected to produce high and stable electromagnetic torque. So that the soft starter with thyristor control can be a solution for conventional soft starters.
\end{abstract}

\section{Introduction}

Three-phase induction motors have several starting methods, including DOL (Direct Online), autotransformer, star-delta. These conventional starting methods still have disadvantages, namely the high current (six to eight times the nominal current) when starting the three-phase induction motor. The weakness of large starting currents in induction motors can be overcome by using a starting method such as a soft starter. The use of this soft starter is not without problems, by reducing the voltage supplied to the induction motor causing the initial electromagnetic torque generated to also experience a reduction. This is because the value of the initial electromagnetic torque is proportional to the value of the voltage supplied to the induction motor. Therefore, this research will analyze the improvement of electromagnetic torque from the conventional soft starter method (voltage control), using a three-phase induction motor soft starter modeling using thyristor control.

The three-phase induction motor is like a horse in the industrial world, because it requires electrical energy that is not too high, so that it can convert electrical energy into mechanical energy efficiently. The main components in a three-phase induction motor are the stator, rotor, and endshield. [1]

Three-phase induction motors work on the electromagnetic principle. In the stator winding, we describe it as 3 windings connected to $\mathrm{Y}$ with a mechanical difference of $120^{\circ}$ between the windings as shown in Figure 2.1 (a). Then the currents flow of Ia, Ib and Ic for each winding with an electric angle difference of $120^{\circ}$ as shown in Figure 1 (b). Each winding will produce a flux that varies with time according to the current flowing in the winding. [2] 


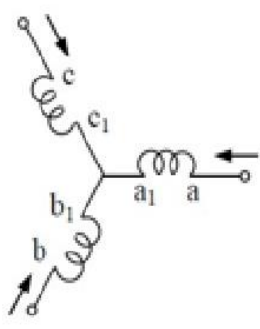

(a)

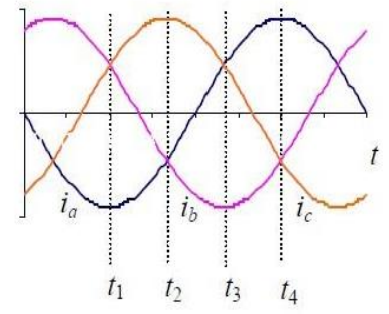

(b)

Figure 1.

(a) The stator winding with a mechanical position difference of $120^{\circ}$

(b) Current ia, ib and ic with a phase difference of $120^{\circ}$ is electric

The rotation speed of the rotating field is the relationship between the number of poles, the voltage frequency, and the synchronous rotation speed as it is known on a synchronous machine, namely :

Where :

$$
\mathrm{n}_{\mathrm{s}}=\frac{120 \mathrm{f} 1}{\mathrm{p}} \square \square
$$

$\mathrm{n}_{\mathrm{s}}=$ Synchronous Speed $(\mathrm{rpm})$

$\mathrm{f} 1=$ Stator Frequency $(\mathrm{Hz})$

$\mathrm{P}=$ Poles

Then, this rotating magnetic field will cut the conductor rod on the rotor. As a result, the induced voltage on the rotor coil and the rotor coil itself is a closed circuit so that it will produce a current. The presence of current in the magnetic field creates a force. Through this force the torque arises which makes the rotor rotate at a certain speed. So that the current in the rotor remains, the induced voltage must be maintained. Therefore we need the relative difference between the stator rotating field speed and the rotor rotating speed (nr). This difference in velocity is known as slip (s). [3]

$$
\mathrm{s}=\frac{\mathrm{ns}^{-} \mathrm{nr}}{\mathrm{nr}} \square 100 \%
$$

\section{Methods}

\subsection{Electromagnetic Torque Three-Phase Induction Motor}

One easy way to determine the electromagnetic torque of an induction motor is with the Thevenin circuit of the equivalent circuit per induction motor phase. The Thevenin circuit of an induction motor can be seen in Figure 2 below. [4]

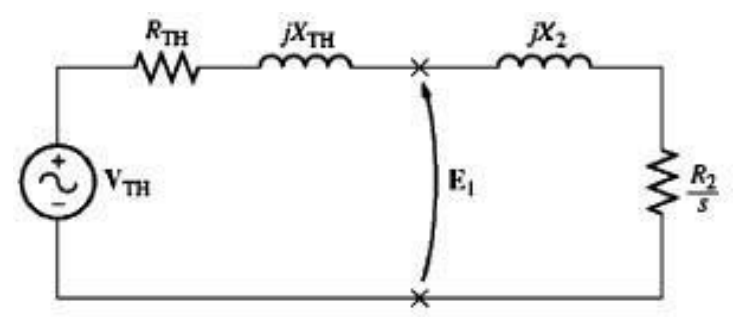

Where :

Figure 2. Thevenin Circuit of Three-phase Induction Motor

$\mathrm{R}_{\mathrm{TH}}=$ Thevenin Resistance

$\mathrm{j} \mathrm{X}_{\mathrm{TH}}=$ Thevenin Reactance

$\mathrm{j} \mathrm{X}_{2}=$ Rotor Reactance

$\mathrm{R}_{2} \quad=$ Rotor Resistance

$\mathrm{V}_{\mathrm{TH}}=$ Thevenin Voltage

$\mathrm{S} \quad=$ Slip 
The Thevenin circuit above describe the Thevenin rod components arranged in series with Thevenin impedance. The determination of Thevenin voltage and impedance can be done by open-circuit to calculate Thevenin voltage and short-circuit to calculate Thevenin impedance on the input side circuit or the stator side of the induction motor as in Figure 3 below [4]
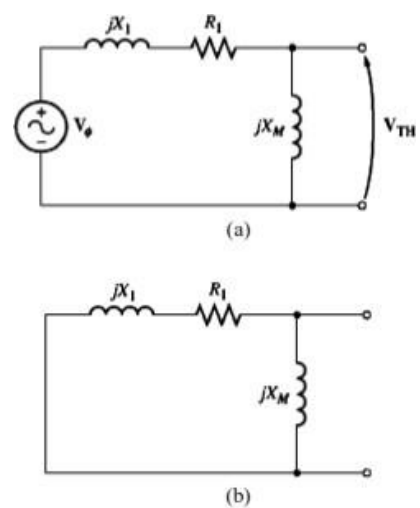

Figure 3.

(a) Equivalent Circuit for Thevenin Voltage

(b) Equivalent Circuit for Thevenin Impedance

Where $\mathrm{jX} 1$ is the stator reactance, $\mathrm{R} 1$ is the rotor resistance, $\mathrm{jXM}$ is the magnetization resistance, and $\mathrm{V} \varnothing$ is the single-phase voltage. From the Thevenin voltage equivalent circuit, Thevenin voltage can be determined with the following equation:

$$
\begin{gathered}
V_{T H}=\frac{j x_{M}}{R_{1}+j X_{1}+j X_{M}} V_{\emptyset} \\
V_{T H}=\frac{x_{M}}{\sqrt{R_{1}^{2}+\left(X_{1}+X_{M}\right)^{2}}} V_{\emptyset}
\end{gathered}
$$

Since the values of $\mathrm{XM} \gg \mathrm{X} 1$ and $\mathrm{XM} \gg>\mathrm{R} 1$, the above equation becomes:

$$
\mathrm{V}_{\mathrm{TH}} \approx \mathrm{V}_{\emptyset} \frac{\mathrm{X}_{\mathrm{M}}}{\mathrm{X}_{1}+\mathrm{X}_{\mathrm{M}}}
$$

Meanwhile, from the Thevenin impedance circuit, Thevenin impedance can be determined with the equation:

$$
\mathrm{Z}_{\mathrm{TH}}=\mathrm{R}_{\mathrm{TH}}+\mathrm{j} \mathrm{X}_{\mathrm{TH}}=\frac{\mathrm{jX}\left(\mathrm{R}_{1}+\mathrm{jX} \mathrm{X}_{1}\right)}{\mathrm{R}_{1}+\mathrm{jX} \mathrm{X}_{1}+\mathrm{j} \mathrm{X}_{\mathrm{M}}}
$$

Because the values of $\mathrm{XM} \gg \mathrm{X} 1$ and $\mathrm{XM}+\mathrm{X} 1>\mathrm{R} 1$, then:

$$
\begin{aligned}
& \mathrm{R}_{\mathrm{TH}} \approx \mathrm{R}_{1}\left(\frac{\mathrm{x}_{\mathrm{M}}}{\mathrm{x}_{1}+\mathrm{X}_{\mathrm{M}}}\right)^{2} \\
& \mathrm{X}_{\mathrm{TH}} \approx \mathrm{X}_{1}
\end{aligned}
$$

The equation for the electromagnetic torque of an induction motor is :

$$
\tau_{\text {ind }}=\frac{3 V_{\mathrm{TH}}^{2} R_{2} / s}{\omega_{\text {sync }}\left[\left(R_{T H}+R_{2} / s\right)^{2}+\left(X_{T H}+X_{2}\right)^{2}\right]}
$$


The equation for electromagnetic torque at start can be obtained by entering the value $\mathrm{S}=1$ in equation (2.8), then :

$$
\tau_{\text {start }}=\frac{3 V_{T H}^{2} R_{2}}{\omega_{\text {sync }}\left[\left(R_{T H}+R_{2}\right)^{2}+\left(X_{T H}+X_{2}\right)^{2}\right]}
$$

Meanwhile, to find out the value of the load torque from the motor power rating can use the following equation :

$$
\tau_{\text {load }}=\frac{P_{\text {out }}}{\omega_{\mathrm{m}}}
$$

Where :

$$
\begin{aligned}
& \tau \text { load }=\text { Load Torque }\left(\mathrm{Kgm}^{2}\right) \\
& \text { Pout }=\text { Motor Output Power }(\text { Watt }) \\
& \omega \mathrm{m} \quad=\text { Load Mechanical Speed }
\end{aligned}
$$

\subsection{Starting Three Phase Induction}

The starting process is the process of feeding an induction motor, either directly or indirectly with a voltage source, so that it impacts on variations in speed, current and torque produced. [5]

2.2.1. DOL (Direct Online) Method

Starting three-phase induction motor process is a process of feeding an induction motor either directly or indirectly with a voltage source so that it impacts on variations in speed, current, and torque produced. [5]

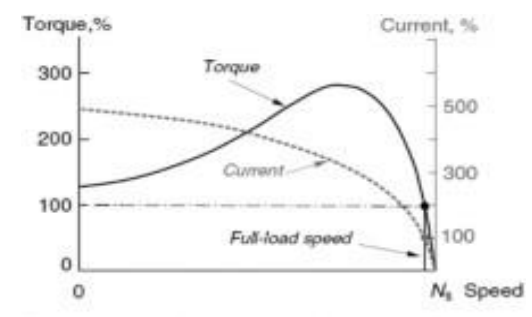

Figure 4. Speed vs Current Torque Curve at Full Load

\subsubsection{Soft Starting Method (Voltage Regulation)}

A simple method of controlling the starting of an induction motor by reducing the AC voltage through the controller, by controlling the voltage with the aim of limiting the current at starting. In this configuration the thyristors are mounted antiparallel to each other, and are mounted in series with the three-phase power source and the stator coil. Each Thyristor is triggered every half cycle and synchronized with the AC voltage source. Thus the triggering angle is a variable value so that each pair of Thyristors that are installed anti-parallel will conduction in accordance with the proportion of the ignition angle.

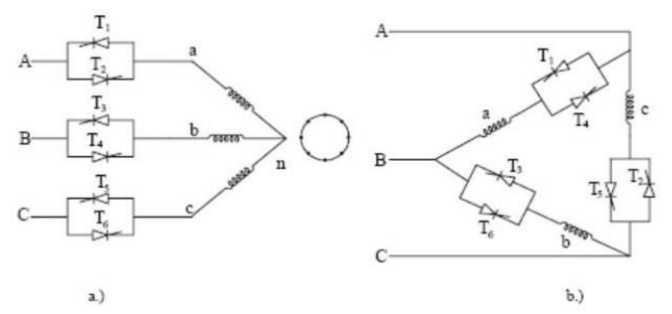

Figure 5.

(a) Wye Circuit

(b) Delta Circuit 


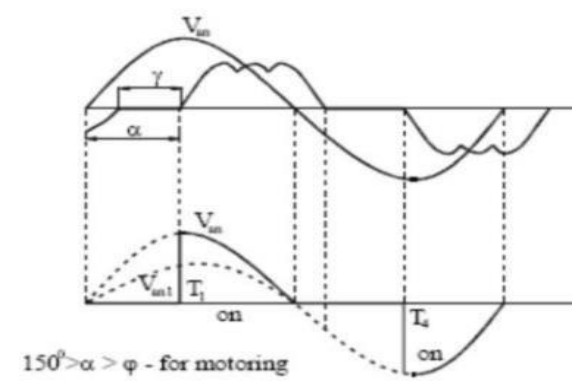

Figure 6. Voltage and Current Curve by Soft Starter Method (Voltage Regulation)

\section{Result and Discussion}

Performance analysis design for three-phase induction motor drive in this paper by comparing with DOL and soft starter method:

1. Starting three-phase induction motor with the DOL (Direct on line) method is connected to a half load and a full load as shown in Figure 7 -14.

2. Starting three-phase induction motor with a voltage regulator soft-starter method connected with half load and full load as shown in Figure 15-22.

3. Starting a three-phase induction motor with a voltage and frequency regulation method using 3 stages of frequency connected with half load and full load as shown in Figure 23-31.

3.1. Analysis Results for Three-Phase Induction Motor Starting with the DOL Method for Half Load The circuit used by simulation as shown in Figure 23 with the following analysis result for output voltage (line to line), output current, rotor speed curve and electromagnetic motor torque curve :

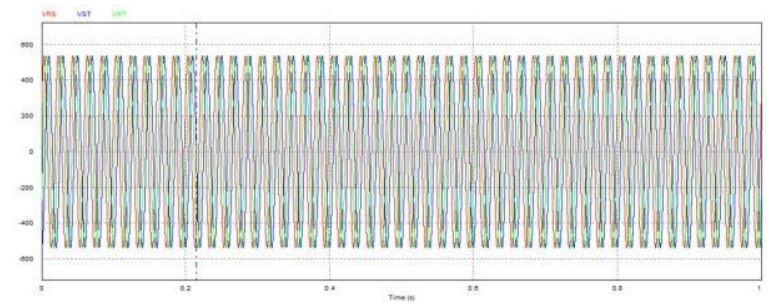

Figure 7. Output Voltage (Line to Line) for the DOL Method with Half Load

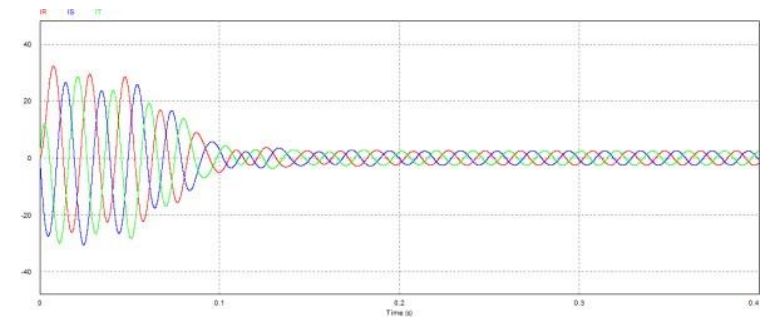

Figure 8. Output Current for the DOL Method with Half Load

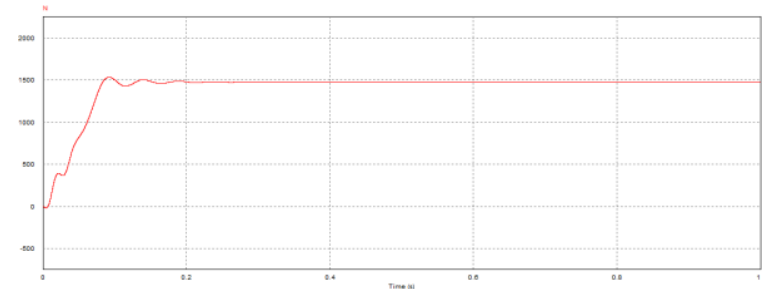

Figure 9. Rotor Speed Curve for the DOL Method with Half Load 


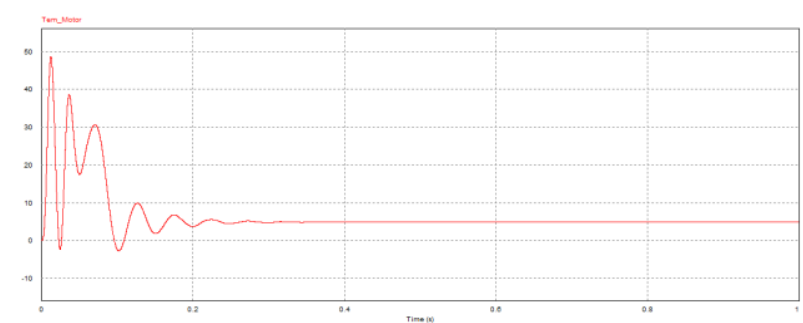

Figure 10. Electromagnetic Motor Torque Curve for DOL Method with Half Load

To reach a steady state, the rotor speed curve in Figure 9 takes 0.18 where the rotor rotates at an average speed of $1476.69 \mathrm{rpm}$. Electromagnetic torque in Figure 10 with normal supply voltage and current, electromagnetic torque at a steady state works at a constant value of 4,925 Nm. The value of 4,925 Nm is in accordance with the half full load borne by the motor which is $4,925 \mathrm{Nm}$. The data result of the voltage and current for DOL method with Half Load as shown in Table 1.

Table 1. Data Result for DOL Method with Half Load

\begin{tabular}{|c|c|c|c|c|c|c|}
\hline \multirow[b]{2}{*}{ Parameter } & \multicolumn{2}{|c|}{ Phase R-S } & \multicolumn{2}{|c|}{ Phase S-T } & \multicolumn{2}{|c|}{ Phase R-T } \\
\hline & \multicolumn{3}{|c|}{$\begin{array}{c}\text { Start }(\mathrm{Sec}) \\
0-0,05\end{array}$} & \multicolumn{3}{|c|}{$\begin{array}{c}\text { Steady }(\mathrm{Sec}) \\
0,05-0,4\end{array}$} \\
\hline Voltage (V) & \multicolumn{6}{|c|}{380} \\
\hline \multirow[t]{2}{*}{ Current (A) } & \multicolumn{2}{|c|}{ Phase R } & \multicolumn{2}{|c|}{ Phase S } & \multicolumn{2}{|c|}{ Phase T } \\
\hline & 29,49 & 2,50 & 26,52 & 2,49 & 28,64 & 2,49 \\
\hline Frequency $(\mathrm{Hz})$ & \multicolumn{6}{|c|}{50} \\
\hline
\end{tabular}

3.2. Analysis Results for Three-Phase Induction Motor Starting with the DOL Method for Full Load

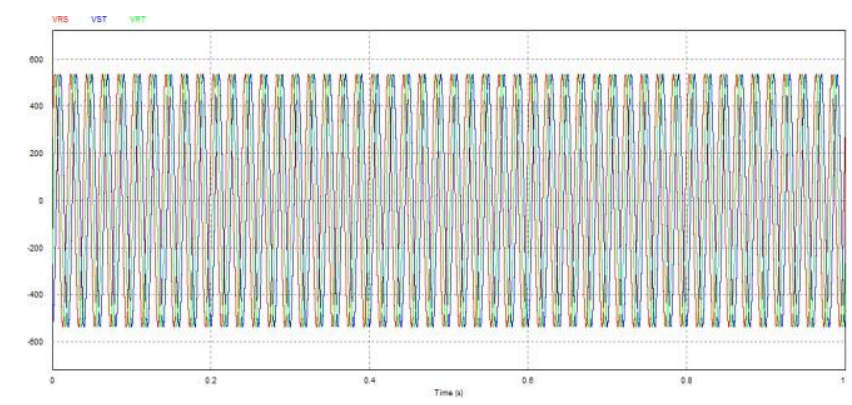

Figure 11. Output Voltage (Line to Line) for the DOL Method with Full Load

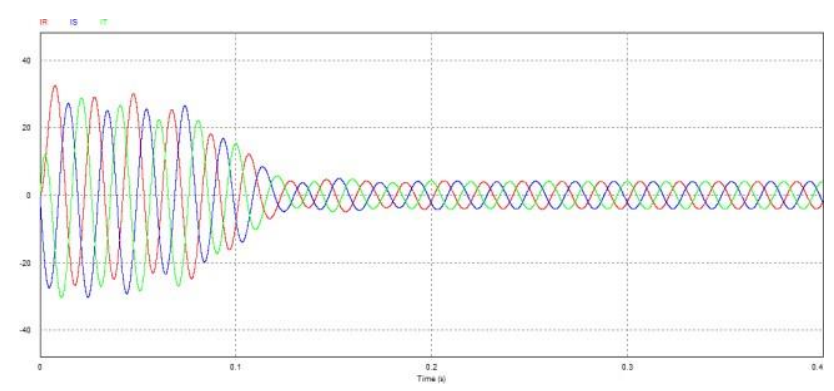

Figure 12. Output Current for the DOL Method with Full Load 


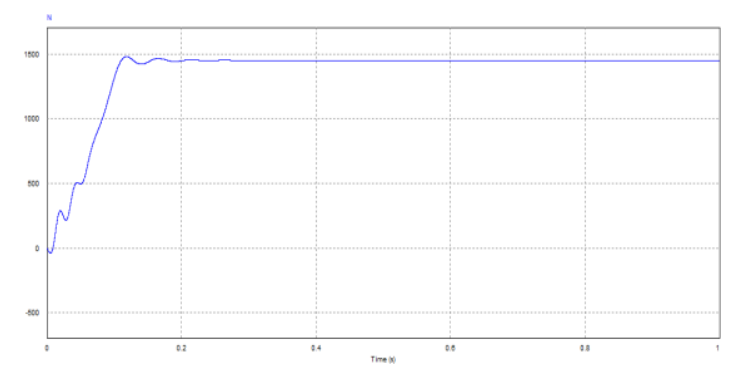

Figure 13. Rotor Speed Curve for the DOL Method with Full Load

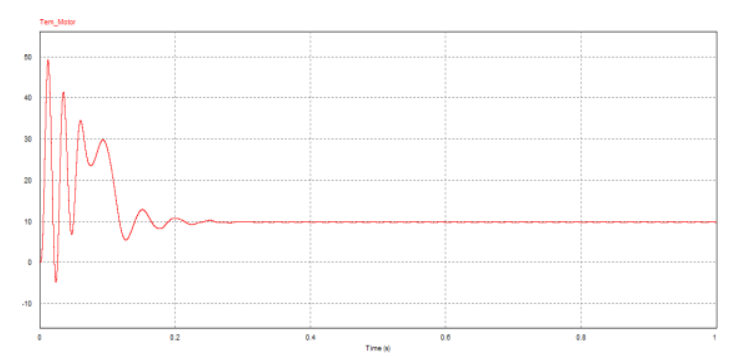

Figure 14. Electromagnetic Motor Torque Curve for DOL method with Full Load

To reach a steady state, the rotor speed curve in Figure 13 takes 0.22 seconds, where the rotor rotates at an average speed of $1451.08 \mathrm{rpm}$. Electromagnetic torque in Figure 14 with normal supply voltage and current, electromagnetic torque at a steady state works at a constant value of $9.85 \mathrm{Nm}$. The value of 9.85 $\mathrm{Nm}$ is in accordance with the half full load borne by the motor which is $9.85 \mathrm{Nm}$. The data result of the voltage and current for DOL method with Full Load as shown in Table 2.

Table 2. Data Result for DOL Method with Full Load

\begin{tabular}{|c|c|c|c|c|c|c|}
\hline \multirow{2}{*}{ Parameter } & \multicolumn{2}{|c|}{ Phase R-S } & \multicolumn{2}{|c|}{ Phase S-T } & \multicolumn{2}{|c|}{ Phase R-T } \\
\hline & \multicolumn{3}{|c|}{$\begin{array}{c}\text { Start }(\mathrm{Sec}) \\
0-0,12\end{array}$} & \multicolumn{3}{|c|}{$\begin{array}{c}\text { Steady }(\mathrm{Sec}) \\
0,12-0,4\end{array}$} \\
\hline Voltage (V) & \multicolumn{6}{|c|}{380} \\
\hline \multirow[t]{2}{*}{ Current (A) } & \multicolumn{2}{|c|}{ Phase R } & \multicolumn{2}{|c|}{ Phase $S$} & \multicolumn{2}{|c|}{ Phase $\mathrm{T}$} \\
\hline & 32,32 & 4,08 & 26,55 & 4,06 & 28,62 & 4,08 \\
\hline Frequency $(\mathrm{Hz})$ & \multicolumn{6}{|c|}{50} \\
\hline
\end{tabular}

3.3. Analysis Results for Three-Phase Induction Motor Starting with the Soft Starter Method for Half Load

The circuit used by simulation as shown in Figure 23 with the following analysis result :

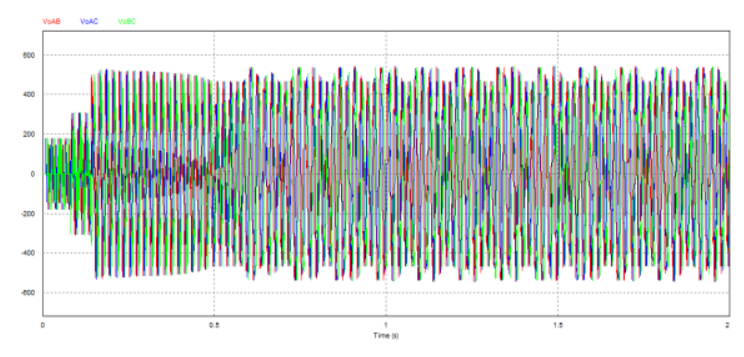

Figure 15. Output Voltage (Line to Line) for the Soft Starter Method with Half Load 


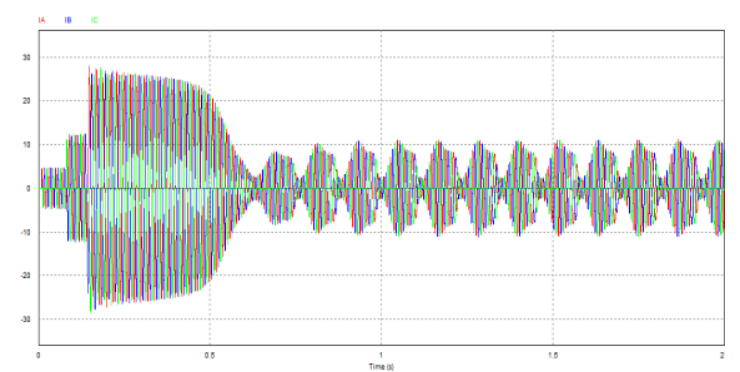

Figure 16. Output Current for the Soft Starter Method with Half Load

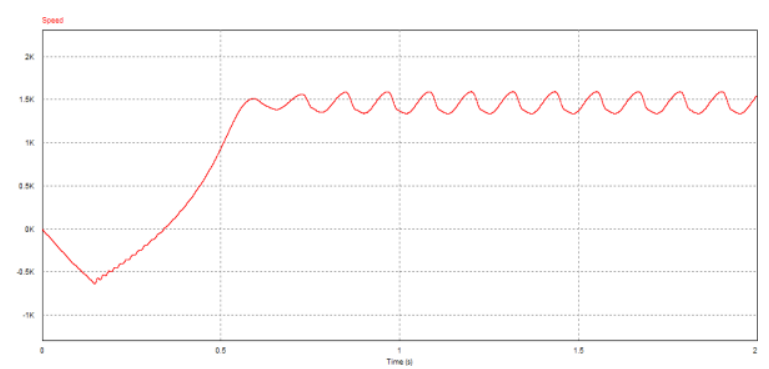

Figure 17. Rotor Speed Curve for the Soft Starter Method with Half Load

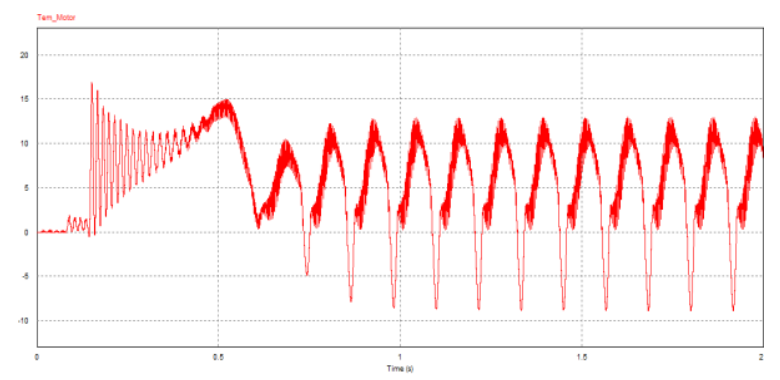

Figure 18. Electromagnetic Motor Torque Curve for Soft Starter Method with Half Load

The rotor speed curve shown in Figure 17 takes 0.6 seconds to reach steady state, where the rotor rotates at an average speed of $1450 \mathrm{rpm}$.

The electromagnetic torque in Figure 18 with the supply voltage and current gradually increasing, the electromagnetic torque at the steady state works at an average value of $7.58 \mathrm{Nm}$. The average value of torque of $7.58 \mathrm{Nm}$ is in accordance with the half-full load that is borne by the motor which is $4,925 \mathrm{Nm}$. This value indicates that the 3-phase induction motor can still rotate at half full load. The data result of the voltage and current for Soft Starter method with Half Load as shown in Table 3.

Table 3. Data Result for Soft Starter Method with Half Load

\begin{tabular}{|c|c|c|c|c|c|c|c|c|}
\hline \multirow{2}{*}{ No } & \multirow{2}{*}{ Trigger Angle } & \multirow{2}{*}{ Time (Sec) } & \multicolumn{3}{|c|}{ Output Voltage (V) } & \multicolumn{3}{c|}{ Current (A) } \\
\cline { 4 - 9 } & & & \multicolumn{3}{|c|}{ Phase } & \multicolumn{3}{c|}{ Phase } \\
\hline 1 & $150^{\circ}$ & $0-0,08$ & 72,93 & 71,93 & 72,83 & 1,77 & 1,69 & 1,68 \\
\hline 2 & $130^{\circ}$ & $0,08-0,14$ & 129,65 & 130,81 & 133,06 & 5,88 & 5,99 & 5,92 \\
\hline 3 & $90^{0}$ & $0,14-0,4$ & 316,68 & 316,68 & 316,57 & 26,57 & 25,80 & 25,66 \\
\hline 4 & Steady State & $0,6-2$ & 325,8 & 325,57 & 325,62 & 4,17 & 4,16 & 4,17 \\
\hline
\end{tabular}


3.4. Analysis Results for Three-Phase Induction Motor Starting with the Soft Starter Method for Full Load

The circuit used by simulation as shown in Figure 23 with the following analysis result :

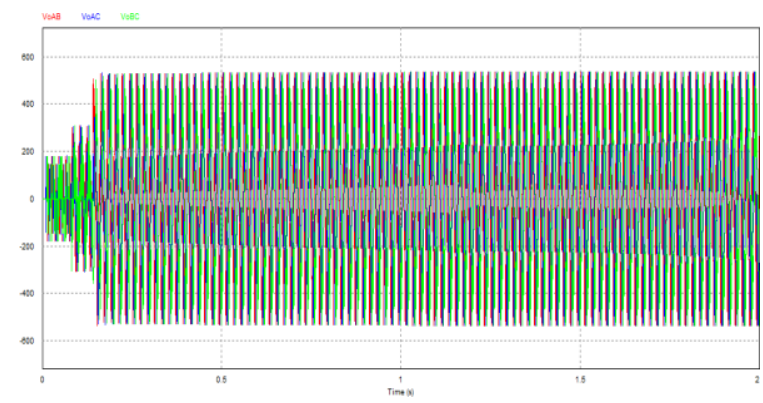

Figure 19. Output Voltage (Line to Line) for the Soft Starter Method with Full Load

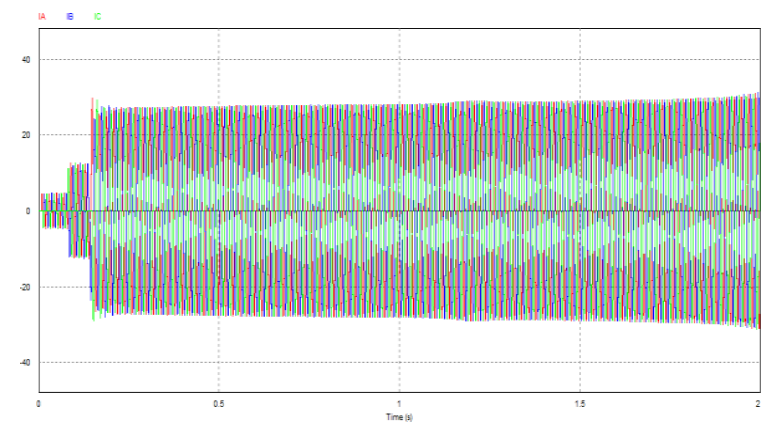

Figure 20. Output Current for the Soft Starter Method with Full Load

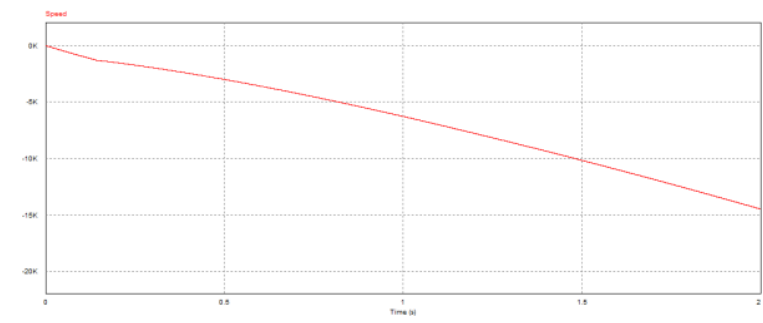

Figure 21. Rotor Speed Curve for the Soft Starter Method with Full Load

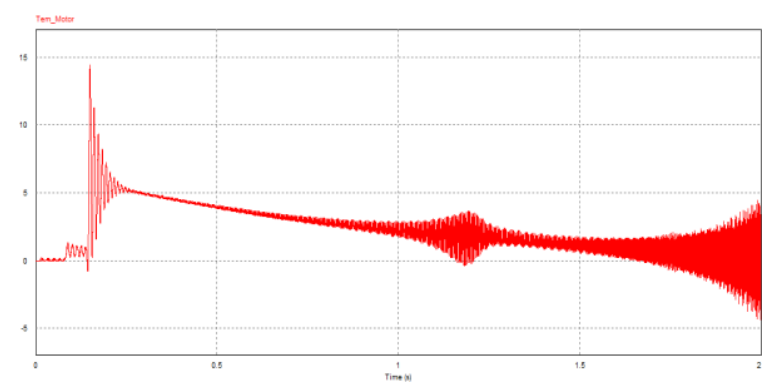

Figure 22. Electromagnetic Motor Torque Curve for Soft Starter Method with Full Load

The rotor speed curve when fully loaded is shown in Figure 21 where the rotor rotates at a speed towards the minus, this curve indicates that the motor cannot rotate if it is loaded with full load. The electromagnetic torque curve is shown in Figure 22 with a gradually increasing supply voltage and current. The curve value indicates that the 3-phase induction motor cannot rotate if it is loaded with full load. The data result of the voltage and current for Soft Starter method with Full Load as shown in Table 4. 
Table 4. Data Result for Soft Starter Method with Full Load

\begin{tabular}{|c|c|c|c|c|c|c|c|c|}
\hline \multirow{2}{*}{ No } & \multirow{2}{*}{ Trigger Angle } & \multirow{2}{*}{ Time (Sec) } & \multicolumn{3}{|c|}{ Output Voltage (V) } & \multicolumn{3}{c|}{ Current (A) } \\
\cline { 4 - 8 } & & & R-S & S-T & R-T & R & S & T \\
\hline 1 & $150^{0}$ & $0-0,08$ & 73,03 & 72,93 & 71,30 & 1,78 & 1,70 & 1,69 \\
\hline 2 & $130^{0}$ & $0,08-0,14$ & 129,72 & 133,55 & 131,55 & 6,00 & 6,14 & 6,02 \\
& & & & & & & & \\
\hline 3 & $90^{0}$ & $0,14-0,4$ & 284,79 & 284,64 & 283,66 & 16,15 & 16,11 & 16,05 \\
\hline 4 & Steady State & $0,6-2$ & 294,34 & 294,24 & 294,38 & 17,42 & 17,42 & 17,41 \\
\hline
\end{tabular}

3.5. Analysis Results for Three-Phase Induction Motor Starting with the New Soft Starter Design (Voltage and Frequency Regulation) for Half Load

The complete circuit of new soft starter design (voltage and frequency regulation) used by simulation as shown in Figure 23 with the following analysis result :

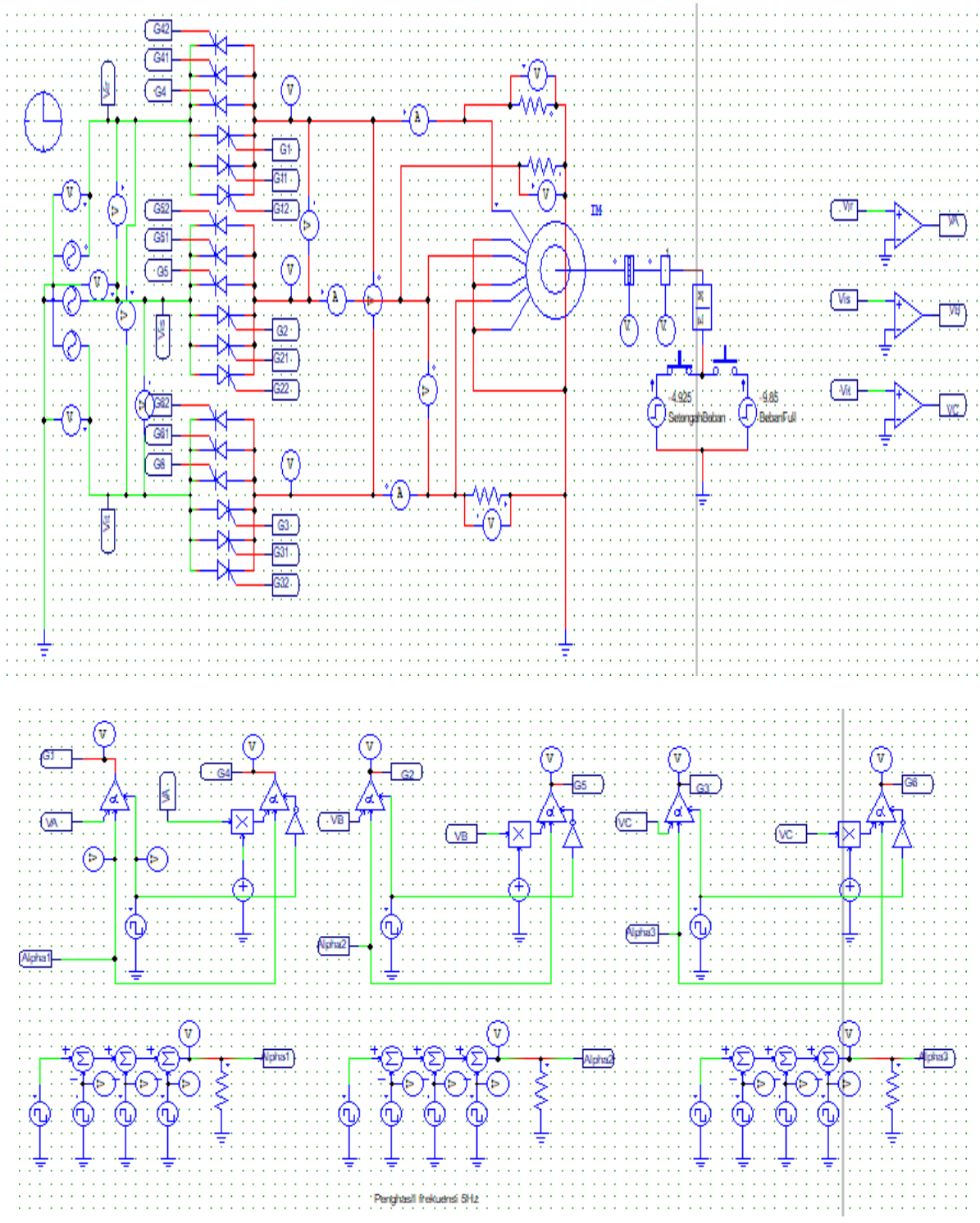




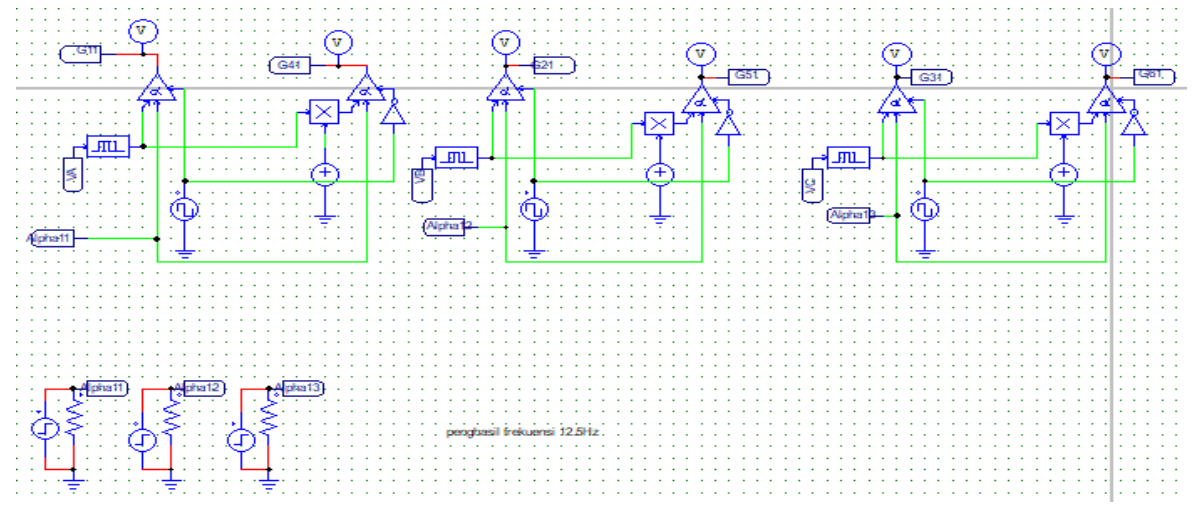

Figure 23. The Circuit of New Soft Starter Design (Voltage and Frequency Regulation)

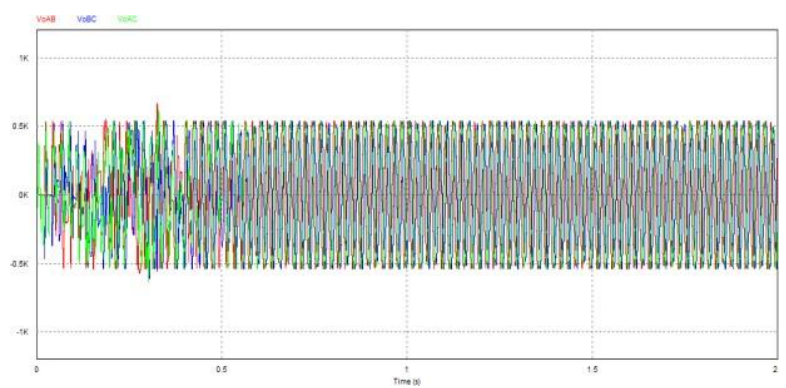

Figure 24. Output Voltage (Line to Line) for the New Soft Starter Design with Half Load

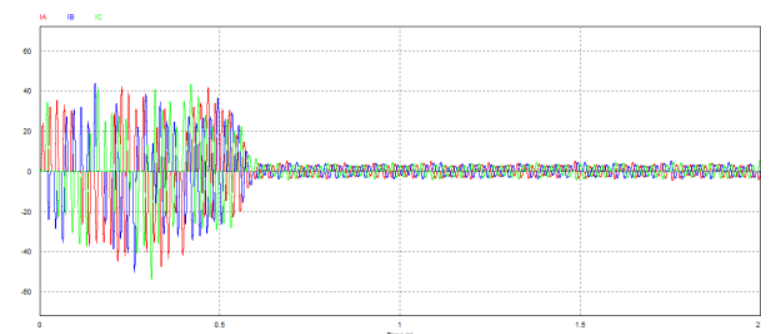

Figure 25. Output Current for the New Soft Starter Design with Half Load

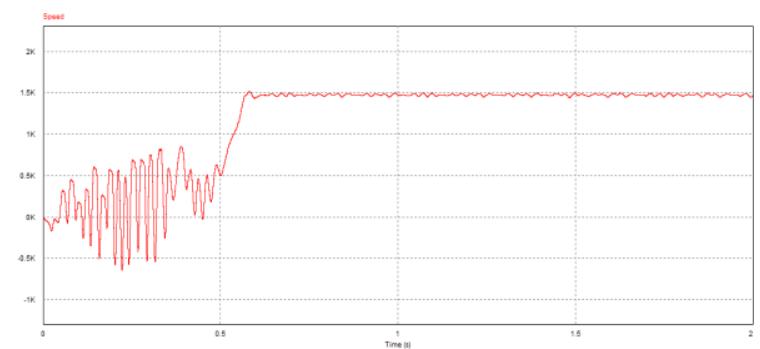

Figure 26. Rotor Speed Curve for the New Soft Starter Design with Half Load

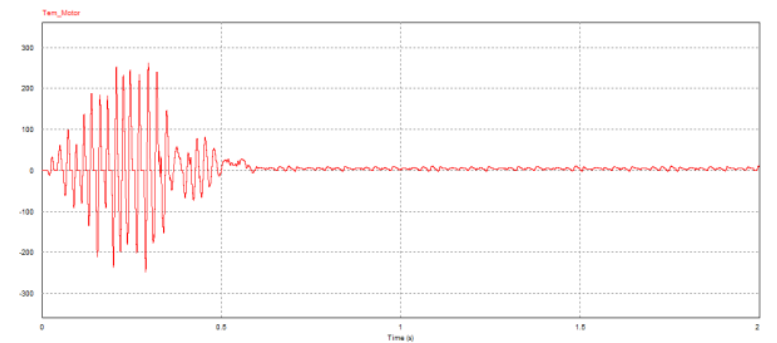

Figure 27. Electromagnetic Motor Torque Curve for New Soft Starter Design with Half Load 
The rotor speed curve is shown in Figure 26 to reach steady state conditions, it takes 0.7 seconds, where the rotor rotates at an average speed of $1471 \mathrm{rpm}$. The electromagnetic torque in Figure 27 increases the voltage and frequency settings, the electromagnetic torque at the steady state works at an average value of $4.97 \mathrm{Nm}$. The average torque value of $4.97 \mathrm{Nm}$ is in accordance with the half-full load borne by the motor which is 4,925 Nm. This value indicates that the 3-phase induction motor can still rotate at half full load. The data result of the voltage and current for new soft starter design with half load as shown in Table 5 .

Table 5. Data Result for New Soft Starter Design with Half Load

\begin{tabular}{|c|c|c|c|c|c|c|c|c|}
\hline \multirow{2}{*}{ No } & \multirow{2}{*}{$\begin{array}{c}\text { Frequency } \\
(\mathrm{Hz})\end{array}$} & \multirow{2}{*}{$\begin{array}{c}\text { Time } \\
(\mathrm{Sec})\end{array}$} & \multicolumn{3}{|c|}{ Output Voltage (V) } & \multicolumn{3}{|c|}{ Current (A) } \\
\cline { 5 - 9 } & & & $\mathrm{R}-\mathrm{S}$ & $\mathrm{S}-\mathrm{T}$ & $\mathrm{R}-\mathrm{T}$ & $\mathrm{R}$ & $\mathrm{S}$ & $\mathrm{T}$ \\
\hline 1 & 5 & $0-0,2$ & 253,53 & 238,26 & 247,54 & 14,82 & 13,22 & 13,46 \\
\hline 2 & 12,5 & $0,2-0,4$ & 322,23 & 327,54 & 336,05 & 18,31 & 17,72 & 18,33 \\
\hline 3 & 50 & $0,4-1$ & 367,17 & 365,78 & 362,97 & 18,35 & 18,89 & 19,18 \\
\hline 4 & Steady State & $1-2$ & 373,74 & 373,68 & 362,97 & 2,1 & 2,12 & 2,09 \\
\hline
\end{tabular}

3.6. Analysis Results for Three-Phase Induction Motor Starting with the New Soft Starter Design (Voltage and Frequency Regulation) for Full Load

The complete circuit of new soft starter design (voltage and frequency regulation) used by simulation as shown in Figure 23 with the following analysis result :

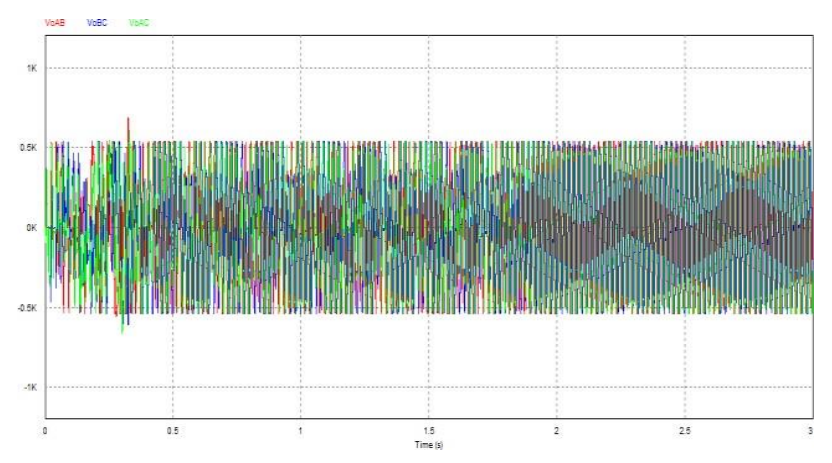

Figure 28. Output Voltage (Line to Line) for the New Soft Starter Design with Full Load

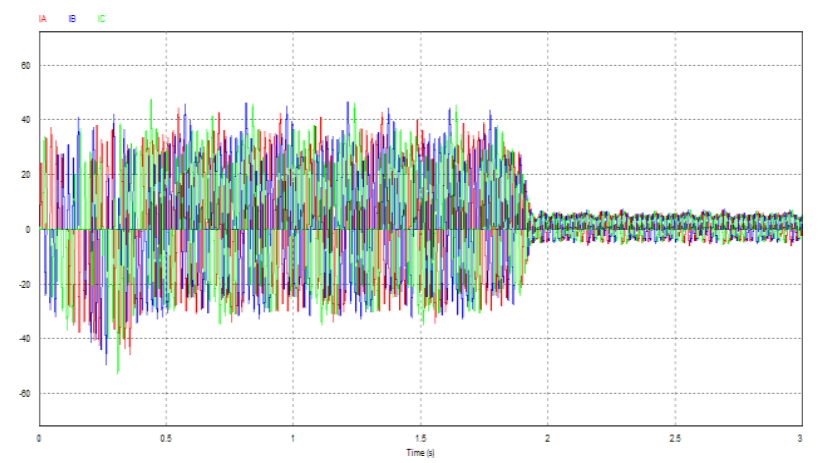

Figure 29. Output Current for the New Soft Starter Design with Full Load 


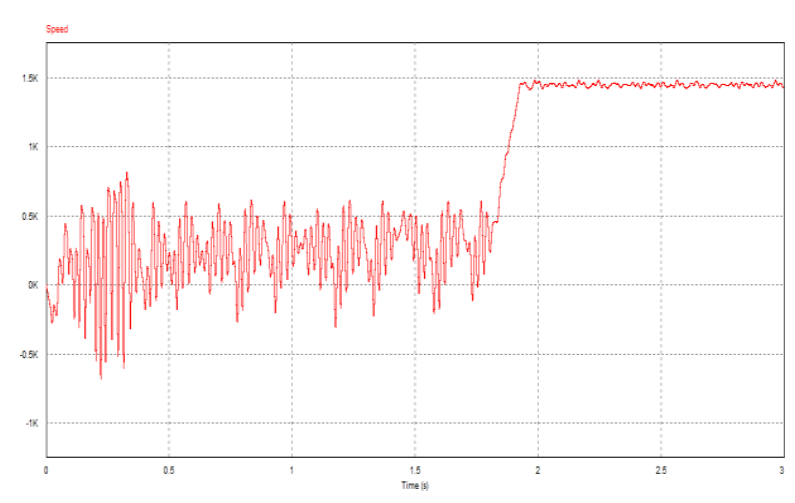

Figure 30. Rotor Speed Curve for the New Soft Starter Design with Full Load

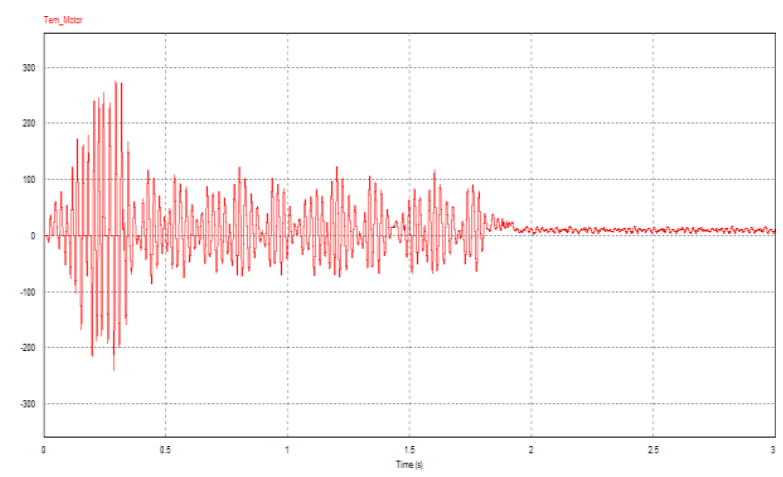

Figure 31. Electromagnetic Motor Torque Curve for New Soft Starter Design with Full Load

The rotor speed curve is shown in Figure 30 to reach steady state conditions, it takes 1.95 seconds, where the rotor rotates at an average speed of $1447 \mathrm{rpm}$. The electromagnetic torque in Figure 31 gradually increases the voltage and frequency settings, the electromagnetic torque at the steady state works at an average value of $9.82 \mathrm{Nm}$. The average torque value of $9.82 \mathrm{Nm}$ is in accordance with the half-full load borne by the motor which is $9.85 \mathrm{Nm}$. This value indicates that the 3-phase induction motor can still rotate at full load. The data result of the voltage and current for new soft starter design with full load as shown in Table 6.

Table 6. Data Result for New Soft Starter Design with Full Load

\begin{tabular}{|c|c|c|c|c|c|c|c|c|}
\hline \multirow{2}{*}{ No } & \multirow{2}{*}{$\begin{array}{c}\text { Frequency } \\
(\mathrm{Hz})\end{array}$} & \multirow{2}{*}{$\begin{array}{c}\text { Time } \\
(\mathrm{Sec})\end{array}$} & \multicolumn{3}{|c|}{ Output Voltage (V) } & \multicolumn{3}{c|}{ Current (A) } \\
\cline { 4 - 9 } & & & $\mathrm{R}-\mathrm{S}$ & $\mathrm{S}-\mathrm{T}$ & $\mathrm{R}-\mathrm{T}$ & $\mathrm{R}$ & $\mathrm{S}$ & $\mathrm{T}$ \\
\hline 1 & 5 & $0-0,2$ & 247,37 & 231,77 & 241,47 & 14,84 & 12,74 & 12,94 \\
\hline 2 & 12,5 & $0,2-0,4$ & 324,09 & 324,96 & 341,34 & 19,47 & 19,11 & 18,12 \\
\hline 3 & 50 & $0,4-1,8$ & 338,15 & 337,06 & 334,05 & 19,60 & 20,21 & 19,56 \\
\hline 4 & Steady State & $1,8-3$ & 341,64 & 341,55 & 339,86 & 3,31 & 3,29 & 3,33 \\
\hline
\end{tabular}

\subsection{Summary of Analysis}

The summary of analysis and performance for DOL, soft starter and new soft starter design as shown in table 7. 


\begin{tabular}{|c|c|c|c|c|c|c|}
\hline \multicolumn{7}{|c|}{ Table 7. Summary of Analysis } \\
\hline No & Starting Method & $\begin{array}{c}\text { Starting Current } \\
\text { (A) }\end{array}$ & $\begin{array}{c}\text { Nominal } \\
\text { Current (A) }\end{array}$ & Start(s) & Speed (rpm) & $\begin{array}{c}\text { Electromagnetic } \\
\text { Torque } \\
\text { (Nm) }\end{array}$ \\
\hline 1 & $\begin{array}{c}\text { DOL } \\
\text { Half Load }\end{array}$ & 29.49 (Phase R) & 2.5 (Phase R) & 0.18 & 1476.69 & 4.925 \\
\hline 3 & $\begin{array}{c}\text { DOL } \\
\text { Full Load }\end{array}$ & 32.32 (Phase R) & 4.08 (Phase R) & 0.22 & 1451.08 & 9.85 \\
\hline 4 & $\begin{array}{c}\text { SoftStarter (Voltage regulation) } \\
\text { with HalfLoad }\end{array}$ & 26.49 (Phase R) & 4.17 (Phase R) & 0.6 & 1450 & 7.58 \\
\hline $\begin{array}{c}\text { Soft Starter (Voltage regulation) } \\
\text { with Full Load }\end{array}$ & 16.15 (Phase R) & 17.42 (Phase R) & - & -1500 & -4.925 \\
\hline 6 & $\begin{array}{c}\text { New SoftStart Design } \\
\text { (Voltage and Frequency } \\
\text { Regulation) with Half Load }\end{array}$ & 19.18 (Phase T) & 2.09 (Phase T) & 0.7 & 1471 & 4.97 \\
\hline $\begin{array}{c}\text { New SoftStart Design(Voltage } \\
\text { and Frequency Regulation) with } \\
\text { Full Load }\end{array}$ & 20.21 (PhaseS) & 3.29 (Phase S) & 1.95 & 1447 & 9.82 \\
\hline
\end{tabular}

Information :

1. The starting current is taken the largest value

2. Negative sign (-) in the electromagnetic speed and torque column indicates that the motor cannot rotate

\section{Conclusion}

Based on the simulation results of several methods of starting a three-phase induction motor where these results have been analyzed and recapitulated, the following conclusions are obtained:

1. Power circuit modeling and control circuits using a thyristor can be used to analyze the method of starting a three-phase induction motor which functions to regulate voltage and frequency.

2. Analysis of the three-phase induction motor starting method by looking at and comparing the parameters of starting current, rotor speed response, electromagnetic torque response and starting time. Starting a 3-phase induction motor with a soft starter method (frequency and voltage regulation) when the load is half full produces a starting current of $19.18 \mathrm{~A}$ in phase $\mathrm{T}$, rotor speed response is $1471 \mathrm{rpm}$ and electromagnetic torque response is $4.97 \mathrm{Nm}$. Start time 0.7 seconds. The advantages of this method are the starting current which is lower than the DOL method (29.49 A in Phase R) and the voltage control soft starter method (26.49 A in Phase R). This method still has shortcomings, the time to start is longer when compared to the DOL method ( 0.18 seconds) and the voltage control soft starter method ( 0.6 seconds).

\section{References}

[1] Pandjaitan, Bonar," Praktik Praktik Proteksi Sistem Tenaga Listrik", Penerbit Andi, Yogyakarta, 2012

[2] Zuhal, "Dasar Tenaga Listrik", Institut Teknologi Bandung, Bandung,1991

[3] Amin,Bahram.,"Induction Motors : Analysis And Torque Control", Springer, Germany, 2001

[4] Hayt, William H dan Jhon, A Buck. "Elektromagnetika Edisi ketujuh", Erlangga, Jakarta, 2006 
[5] Riyadi, Dwi H. "Soft Starter Pada Motor Induksi 3 Fasa”, Tugas Akhir, Indonesia, Teknik Elektro, UNDIP, 2013Ardian Selenkovyski, "Solid ion epitaxy", Skripsi Sarjana, Institut Teknologi Lembang, Indonesia, 1997, p. 50

[6] H. M. Hu, C. X. Mao, J. M. Lu and Y. X. Yu, "The Torque Oscillation Study in the Motor Soft Starting Process with Discrete Variable Frequency Method," Electrical Machines and Systems, 2008, ICEMS2008, pp.1686-1690, October 2008.Ardian Selenkovyski, "Unisotropic solid ion epitaxy", Desertasi Doktor, Institut Teknologi Lembang, Indonesia, 2002, p. 44

[7] Penrose, Howard W. "Motor Circuit Analysis Theory, Applications and Energy Analysis Winding Analysis for Motors and Transformers",Success By Design, USA, 2002

[8] G. Zenginobuz. I Cadirci M. ermis and C Barlak, "Soft Starting of Large Induction Motors at constant Current with Minimized Starting Torque Pulsations", Industry Applications Conference ,2000. Conference Record of the 2000 IEEE, vol.3, 2000, P1593-1604, 2000

[9] www.PDFstaff.ui.ac.id

[10] www.IEEE.com 